\title{
Chasing after Non-cyanobacterial Nitrogen Fixation in Marine Pelagic Environments
}

OPEN ACCESS

Edited by:

Angela Landolfi,

GEOMAR Helmholtz Centre for Ocean

Research Kiel (HZ), Germany

Reviewed by:

Natalie Loick-Wilde,

Leibniz Institute for Baltic Sea

Research (LG), Germany

Mark Moore,

University of Southampton,

United Kingdom

*Correspondence:

Pia H. Moisander

pmoisander@umassd.edu

Specialty section:

This article was submitted to

Aquatic Microbiology,

a section of the journal

Frontiers in Microbiology

Received: 17 June 2017

Accepted: 25 August 2017

Published: 08 September 2017

Citation:

Moisander PH, Benavides $M$, Bonnet S, Berman-Frank I, White AE and Riemann L (2017) Chasing after Non-cyanobacterial Nitrogen Fixation

in Marine Pelagic Environments.

Front. Microbiol. 8:1736.

doi: 10.3389/fmicb.2017.01736

\author{
Pia H. Moisander ${ }^{1 *}$, Mar Benavides ${ }^{2}$, Sophie Bonnet ${ }^{3}$, llana Berman-Frank ${ }^{4}$, \\ Angelicque E. White ${ }^{5}$ and Lasse Riemann ${ }^{2}$
}

${ }^{1}$ Department of Biology, University of Massachusetts Dartmouth, North Dartmouth, MA, United States, ${ }^{2}$ Marine Biology Section, Department of Biology, University of Copenhagen, Helsingør, Denmark, ${ }^{3}$ Centre National de la Recherche Scientifique, IRD, Aix-Marseille Université, Université de Toulon, Marseille, France, ${ }^{4}$ Mina and Everard Goodman Faculty of Life Sciences, Bar-Ilan University, Ramat Gan, Israel, ${ }^{5}$ College of Earth, Ocean, and Atmospheric Sciences, Oregon State University, Corvallis, OR, United States

Traditionally, cyanobacterial activity in oceanic photic layers was considered responsible for the marine pelagic dinitrogen $\left(\mathrm{N}_{2}\right)$ fixation. Other potentially $\mathrm{N}_{2}$-fixing bacteria and archaea have also been detected in the pelagic water column, however, the activity and importance of these non-cyanobacterial diazotrophs (NCDs) remain poorly constrained. In this perspective we summarize the $\mathrm{N}_{2}$ fixation rates from recently published studies on photic and aphotic layers that have been attributed to NCD activity via parallel molecular measurements, and discuss the status, challenges, and data gaps in estimating noncyanobacterial $\mathrm{N}_{2}$ fixation NCNF in the ocean. Rates attributed to NCNF have generally

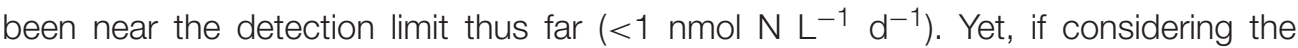
large volume of the dark ocean, even low rates of NCNF could make a significant contribution to the new nitrogen input to the ocean. The synthesis here shows that nifH transcription data for NCDs have been reported in only a few studies where $\mathrm{N}_{2}$ fixation rates were detected in the absence of diazotrophic cyanobacteria. In addition, high apparent diversity and regional variability in the NCDs complicate investigations of these communities. Future studies should focus on further investigating impacts of environmental drivers including oxygen, dissolved organic matter, and dissolved inorganic nitrogen on NCNF. Describing the ecology of NCDs and accurately measuring NCNF rates, are critical for a future evaluation of the contribution of NCNF to the marine nitrogen budget.

Keywords: bacteria, diazotroph, DOM, mesopelagic, nifH, nitrogenase, oxygen minimum zone

\section{INTRODUCTION}

Biological dinitrogen $\left(\mathrm{N}_{2}\right)$ fixation produces biologically available nitrogen $(\mathrm{N})$ through reduction of atmospheric $\mathrm{N}_{2}$ to ammonium $\left(\mathrm{NH}_{4}^{+}\right)$(Postgate, 1998). In oligotrophic marine environments, $\mathrm{N}_{2}$ fixation can provide $\sim 50 \%$ of the "new" N (Karl et al., 2002; Capone et al., 2005; Berthelot et al., 2017), and probably contributes more in hot spots such as the Western Tropical South Pacific (Bonnet et al., 2017). $\mathrm{N}_{2}$ fixation (diazotrophy) is catalyzed by the enzyme nitrogenase (Mortenson and Thorneley, 1979; Postgate, 1998). The nifH gene that encodes the dinitrogenase reductase is distributed in many phylogenetic groups of bacteria and archaea (Chien and Zinder, 1996), and used to assess the diversity and expression of the enzyme in marine diazotrophs (Zehr et al., 2003). 
Cyanobacteria have traditionally been considered the most important diazotrophs in the ocean. The predominantly described taxa include the filamentous, bloom-forming Trichodesmium, heterocystous, symbiotic groups (e.g., diatomdiazotroph associations), and the unicellular cyanobacteria UCYN-A (Candidatus Atelocyanobacterium thalassa), UCYNB (Crocosphaera watsonii), and UCYN-C (Zehr, 2011). Early molecular studies also reported the presence of noncyanobacterial diazotrophs (NCDs) (Kirshtein et al., 1991; Zehr et al., 1995, 1998). These findings stimulated recent research on diversity, composition, and ecology of marine NCDs (Bombar et al., 2016), leading to a currently perceived emergence of a new paradigm: non-cyanobacterial $\mathrm{N}_{2}$ fixation (NCNF). Extensive research on free-living and symbiotic NCDs in soils has provided evidence of the activity, regulation, and the significance of these processes in terrestrial ecosystems (Postgate, 1998; Herridge et al., 2008; Hayat et al., 2010). While the diversity and abundance of marine NCDs indicate that NCNF could potentially have a large impact on the marine $\mathrm{N}$ budget, at present, the activity and contribution of marine $\mathrm{NCNF}$ to total $\mathrm{N}_{2}$ fixation remain poorly constrained.

In many oceanic waters, NCD sequences dominate the nifH gene pool (Riemann et al., 2010; Farnelid et al., 2011), and detection of transcripts of some of the NCD nifH genes suggests that at least some of the NCDs fix $\mathrm{N}_{2}$ in the oceanic water column and sediments (Bird et al., 2005; Church et al., 2005b; Halm et al., 2012; Brown and Jenkins, 2014; Moisander et al., 2014; BentzonTilia et al., 2015b). However, gene expression cannot be equated with active $\mathrm{N}_{2}$ fixation rates without evidence of cell-specific activity. Current broadly available methods cannot discern the relative contribution of cyanobacteria and NCDs to measured $\mathrm{N}_{2}$ fixation rates. The contribution of NCNF could be studied by parallel rate measurements and molecular detection in areas where cyanobacterial diazotrophs are typically not present (such as the oceanic water column below the euphotic layer, i.e., aphotic waters). Here we summarize data from studies where $\mathrm{N}_{2}$ fixation rates were reported in parallel to molecular characterization of NCDs when cyanobacterial diazotrophs were not detected (presence and/or expression of the nifH gene; Table 1). Presumed NCNF rates ranged from undetectable to 8 and $0.89 \mathrm{nmol} \mathrm{N} \mathrm{L}{ }^{-1}$ $\mathrm{d}^{-1}$ in photic and aphotic studies, respectively (Table 1). The goal of this perspective is to synthesize emerging trends and data gaps from these studies and highlight future research directions.

\section{NCNF IN PHOTIC WATERS}

Most early studies of oceanic $\mathrm{N}_{2}$ fixation (Montoya et al., 1996; Karl et al., 2002; Hood et al., 2004; Mahaffey et al., 2005; Mulholland et al., 2006) and diazotroph diversity and activity (Zehr, 2011) focused on photic waters and cyanobacterial diazotrophs. Traditionally, the photic layer has been considered an optimal environment selecting for cyanobacterial $\mathrm{N}_{2}$ fixation, as abundant light energy (harnessed via photosynthesis) supplies the high energetic demands of the $\mathrm{N}_{2}$ fixation process, while dissolved inorganic nitrogen (DIN) limits non-diazotrophic autotrophs. Yet, since the first molecular studies (Zehr et al., 1998), nifH sequence libraries have revealed diverse NCD phylotypes from surface waters of various oceans and estuaries (Falcon et al., 2004; Church et al., 2005a; Langlois et al., 2005; Hewson et al., 2007; Moisander et al., 2008; Foster et al., 2009; Farnelid et al., 2011; Halm et al., 2012; BentzonTilia et al., 2015b; Messer et al., 2016). Transcripts from a range of NCD groups have been recovered in surface layers (Man-Aharonovich et al., 2007; Halm et al., 2012; Loescher et al., 2014). One of the few consistent NCDs in photic layers is a gamma-proteobacterial cluster of sequences (termed $\gamma$ 24774A11, Gamma A, or UMB; representatives of the same phylotype). Gamma A shows a wide distribution and expression of the nifH gene (Bird et al., 2005; Church et al., 2005b; Moisander et al., 2014; Langlois et al., 2015). This group appears to be broadly distributed across tropical and subtropical surface waters compared with cyanobacterial diazotrophs (Moisander et al., 2014; Bonnet et al., 2015; Langlois et al., 2015). Its presence exclusively in surface layers suggests either reliance on a photosynthetic machinery, rhodopsin, or photosynthesis products from other organisms. Once cultivated or its genome assembled, we can learn more about its autecology. A few other studies have detected $\mathrm{N}_{2}$ fixation from photic layers in the reported absence of cyanobacterial sequences (Yogev et al., 2011; Blais et al., 2012). However, due to the difficulty of demonstrating the absence of cyanobacterial diazotrophs, it has generally been difficult to prove that NCNF is active in photic layers.

The nitrogenase enzyme may be downregulated or inactivated by $\mathrm{NH}_{4}^{+}$(Zehr et al., 1997). As typically assumed for cyanobacterial diazotrophs (Zehr, 2011), DIN could negatively impact NCDs directly (physiological inhibition) or indirectly (NCDs outcompeted by faster growing non-diazotrophs). However, DIN availability may not always have immediate negative effects on NCDs. For example, Gamma A transcripts and Cluster III diazotrophs (Chien and Zinder, 1996) were found in the presence of micromolar concentrations of DIN in the upper layers of the Arabian Sea (Bird and Wyman, 2013). $\mathrm{N}_{2}$ fixation rates were also detected in the Benguela Upwelling System in the presence of micromolar nitrate and in the absence of cyanobacterial diazotrophs (Sohm et al., 2011). In other surface waters (Eastern Tropical South Pacific; ETSP), $\mathrm{N}_{2}$ fixation rates were similarly reported in the absence of cyanobacterial diazotrophs and presence of high DIN (Fernandez et al., 2011; Dekaezemacker et al., 2013; Gradoville et al., 2017). In Indian Ocean surface waters with a shallow nitracline, $\mathrm{N}_{2}$ fixation rates were reported in parallel with up to $10^{4} \mathrm{nifH}$ gene copies $\mathrm{L}^{-1}$ of Gamma $\mathrm{A}$, while cyanobacterial groups were undetectable (Shiozaki et al., 2014). Collectively these field studies suggests that NCDs may have a low sensitivity to DIN (Knapp, 2012), but recent work with cultivated NCDs suggest that responses to DIN may be strain specific (Bentzon-Tilia et al., 2015a).

PCR amplification biases likely influence our current data and conclusions of studies on NCDs. A recent study using metagenomic data from the TARA Oceans survey reports 


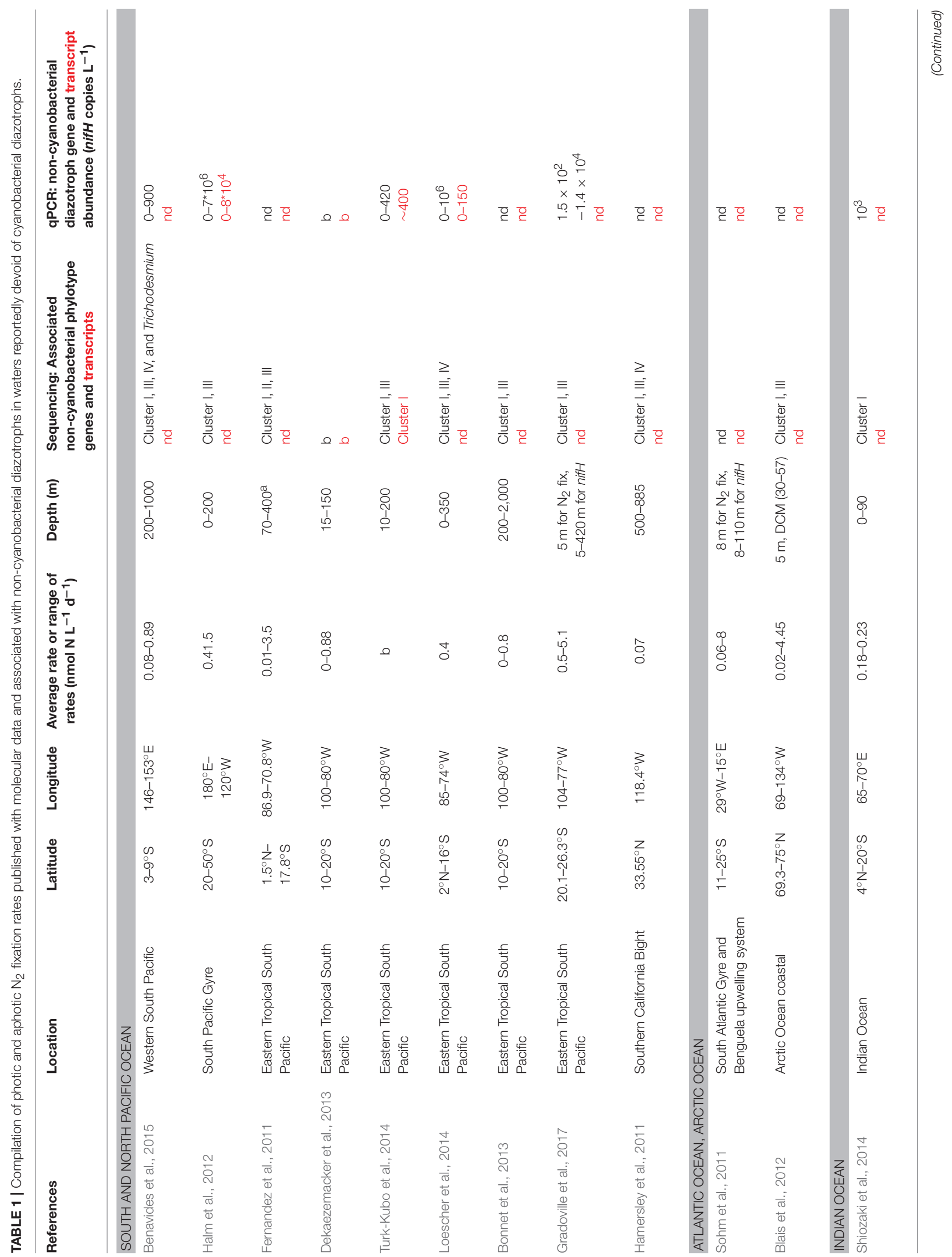




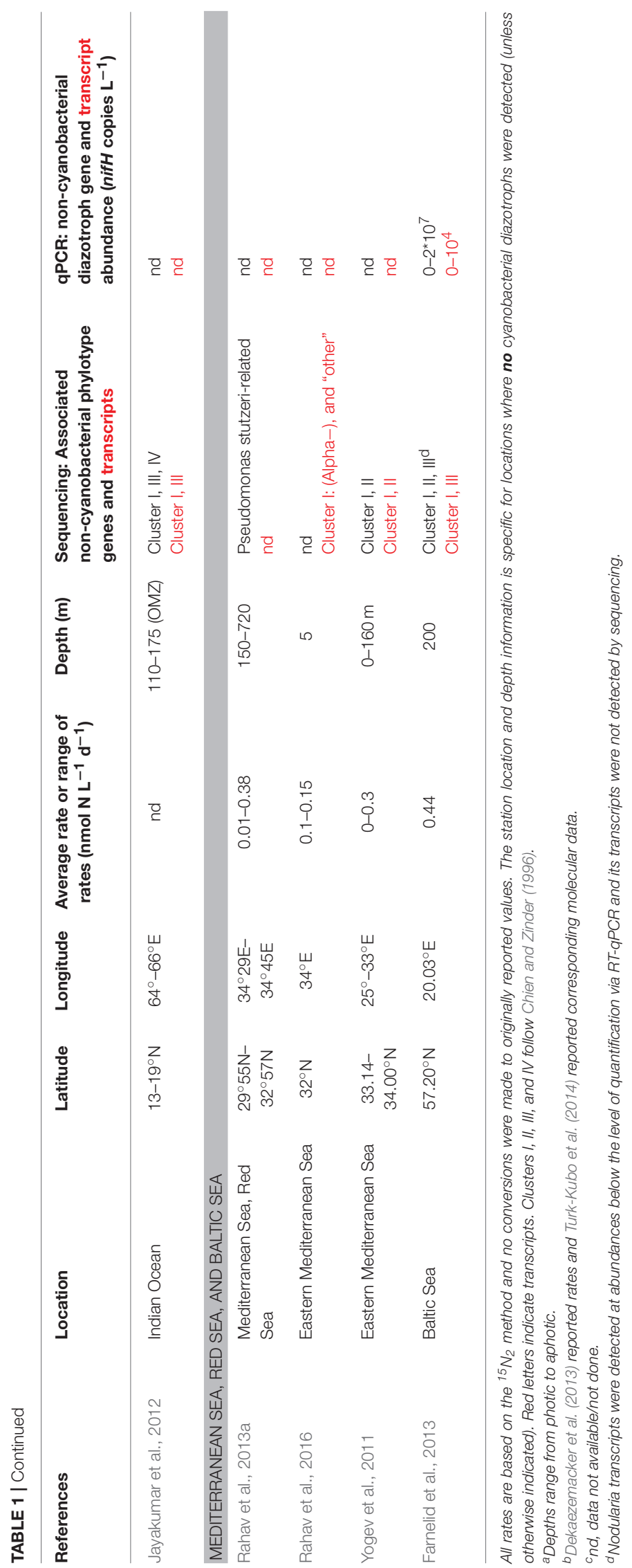

presence of nitrogenase containing Planctomycetes in oceanic photic waters and suggests they have a substantially greater abundance than the NCDs reported based on past PCR approaches (Delmont et al., 2017).

\section{NCNF IN APHOTIC WATERS AND OXYGEN DEFICIENT ZONES}

Several studies have recently reported $\mathrm{N}_{2}$ fixation rates in the aphotic ocean where active autotrophic cyanobacterial diazotrophy is not expected. Early evidence for aphotic $\mathrm{N}_{2}$ fixation showed proteobacterial and archaeal diazotrophs and $\mathrm{N}_{2}$ fixation in hydrothermal vent fluids (Mehta and Baross, 2006). Deep-sea sediment archaea fixing $\mathrm{N}_{2}$ apparently function in associations with anaerobic methane oxidizers (Dekas et al., 2009, 2014). Proteobacterial nifH sequences were reported from the meso- to abyssopelagic water column in different oceans (Hewson et al., 2007; Moisander et al., 2008).

Laboratory studies have shown that nitrogenase activity in cells is reduced under increasing concentrations of oxygen, and the enzyme is irreversibly modified by oxygen in vitro (Fay, 1992; Berman-Frank et al., 2008). Thus, oxygen deficient zones (ODZs) that may span photic and aphotic layers could serve as sites of $\mathrm{N}_{2}$ fixation due to low oxygen, in parallel with $\mathrm{N}$ losses from these zones (Deutsch et al., 2007). The first studies reporting planktonic $\mathrm{N}_{2}$ fixation rates in aphotic waters were ones associated with ODZs in the Eastern Tropical North Pacific Ocean (ETNP) (Hamersley et al., 2011) and ETSP (Fernandez et al., 2011; Dekaezemacker et al., 2013). $\mathrm{N}_{2}$ fixation rates were reported in mesopelagic waters down to 400 and $800 \mathrm{~m}$, and abyssopelagic waters down to 2,000 m (Fernandez et al., 2011; Bonnet et al., 2013; Loescher et al., 2014). These rates were attributed to various NCD DNA sequences, including Cluster I (Proteobacteria), II and III (Turk-Kubo et al., 2014). $\mathrm{N}_{2}$ fixation in the presence of NCD nifH expression was also reported in the aphotic ODZ of the Baltic Sea (Farnelid et al., 2013), and in the ODZ of the Arabian Sea (Jayakumar et al., 2012). These studies suggest that NCNF may be active in ODZs, however evidence of the relationship between oxygen and NCNF is variable. $\mathrm{N}_{2}$ fixation in the aphotic Western Tropical South Pacific had a negative correlation with dissolved oxygen (Benavides et al., 2015). However, mesopelagic $\mathrm{N}_{2}$ fixation rates in the Mediterranean Sea were reported from fully oxygenated waters (Rahav et al., 2013a), or were negatively correlated with apparent oxygen utilization values (i.e., $\mathrm{N}_{2}$ fixation was higher in more recently ventilated waters; Benavides et al., 2016). Gammaproteobacteria (Cluster I) and Cluster III generally dominated the nifH DNA sequences in these studies. In addition, both spatial coupling (Deutsch et al., 2007) and decoupling (Knapp et al., 2016; Bonnet et al., 2017) of $\mathrm{N}_{2}$ fixation and denitrification has been proposed. Collectively these studies suggest that NCNF is occurring in aphotic waters, and may correlate with oxygen availability, but the mechanisms by which oxygen and possibly other factors regulate NCNF in aphotic waters remain poorly known. 


\section{THE POTENTIAL ROLE OF DISSOLVED ORGANIC MATTER (DOM) IN SUPPORTING NCNF}

Organic particles may provide a site of low oxygen and a source of DOM that both can benefit specific bacterial attachment (Thiele et al., 2015; Dang and Lovell, 2016). If NCDs are heterotrophic (Riemann et al., 2010), overall DOM availability should play a role in controlling their growth and activity (Kirchman, 1990). Genomic and physiological analyses have confirmed that gamma- and alphaproteobacterial diazotrophs isolated from the Baltic Sea are heterotrophic and contain genes responsible for DOM metabolism (Bentzon-Tilia et al., 2015a). Evidence for DOM influence on NCDs was reported from the South Pacific Gyre (SPG) photic layers (Halm et al., 2012) and in the Mediterranean Sea (Rahav et al., 2016), where DOM originating from primary production was suggested to impact $\mathrm{N}_{2}$ fixation. Most of the SPG sequences were gammaproteobacterial, but represented different groups from those found in the ETSP (Fernandez et al., 2011; Turk-Kubo et al., 2014). Mesopelagic $\mathrm{N}_{2}$ fixation rates had a positive correlation with relatively labile DOM (Benavides et al., 2015), and were enhanced upon the addition of sugars, amino acids, or transparent exopolymeric particles (Bonnet et al., 2013; Rahav et al., 2013a; Loescher et al., 2014; Benavides et al., 2015).

In the eastern Mediterranean Sea, $\mathrm{N}_{2}$ fixation in the photic zone was uncoupled from primary production and correlated significantly and positively with bacterial production (Rahav et al., 2013b). However, even in coastal waters with high dissolved inorganic nutrient loads, organic carbon stimulated light and dark $\mathrm{N}_{2}$ fixation in a community containing cyanobacterial and NCD nifH phylotypes (Rahav et al., 2016). Saharan dust addition (serving potentially as a source of trace elements, nutrients, and/or DOM) enhanced $\mathrm{N}_{2}$ fixation and both NCD (Gamma A) and cyanobacterial diazotroph abundances in the North Atlantic (Langlois et al., 2012). Gamma A abundances were also enhanced by addition of sugars in the South Pacific (Moisander et al., 2012). Many cyanobacteria, including diazotrophs, take up organic forms of carbon (Hietanen et al., 2002; Church et al., 2004; Moisander et al., 2012; Benavides et al., 2017) thus rates of $\mathrm{N}_{2}$ fixation in mixed communities, measured after DOM amendments, may reflect responses of both cyanobacterial and NCDs. Whether some marine NCDs also use light as an energy source remains to be demonstrated (Bombar et al., 2016).

\section{CURRENT AND FUTURE CHALLENGES}

The data synthesis here shows that while $\mathrm{N}_{2}$ fixation rates have been reported by several studies in waters dominated by NCD nifH sequences (Table 1), most studies of NCDs did not measure transcription. The nifH DNA sequences often do not appear as transcripts in the same samples, suggesting that some of the organisms are not active (Moisander et al., 2006; Short and Zehr, 2007; Yogev et al., 2011; Halm et al., 2012; Severin et al., 2015), thus it would be misleading to use nifH gene (DNA) data as proof for NCNF. Despite the common detection of cyanobacterial and NCD nifH in DNA sequence libraries and, at times, in transcripts, only a few studies from surface layers reported the absence of cyanobacterial diazotrophs when $\mathrm{N}_{2}$ fixation rates were detected (Table 1). Due to various methodological constraints, proving the absence of low numbers of cyanobacterial cells in a sample is difficult, if not impossible, yet such low abundance may be sufficient to result in detectable $\mathrm{N}_{2}$ fixation rates. Aphotic waters may be considered a good case study for NCNF, as photoautotrophic $\mathrm{N}_{2}$ fixation in these waters is conceivably absent. However, the common detection of diazotrophic cyanobacteria in aphotic layers (Hamersley et al., 2011; Farnelid et al., 2013; Benavides et al., 2015), possibly due to either settling material that could be viable upon experimental incubations (Agusti et al., 2015), or caused by contamination during sampling, complicate attributing measured aphotic $\mathrm{N}_{2}$ fixation rates to NCDs alone. Overall, the measured rates of in situ aphotic $\mathrm{N}_{2}$ fixation are higher than the parallel abundance and transcript numbers of NCDs would potentially support. Moreover, the reported cell-specific rates of NCDs are under debate (Turk-Kubo et al., 2014; Benavides et al., 2015; BentzonTilia et al., 2015a; Gradoville et al., 2017).

Various factors of the ${ }^{15} \mathrm{~N}_{2}$ method, such as uncertainties in the ${ }^{15} \mathrm{~N}$-labeling step, influence $\mathrm{N}_{2}$ fixation rate determination (Mohr et al., 2010; Grosskopf et al., 2012; Wilson et al., 2012). In addition, commercially available ${ }^{15} \mathrm{~N}_{2}$ gases are at times contaminated with substrates other than $\mathrm{N}_{2}$ (Dabundo et al., 2014), which could lead to false positive NCNF rates. An additional source of uncertainty that must be considered when assessing minimum quantifiable $\mathrm{N}_{2}$ fixation rates is the concentration and isotopic composition of particulate organic $\mathrm{N}$ $(\mathrm{PON})$, which at typical concentrations requires large volumes in incubations (usually $>4 \mathrm{~L}$ ) to constrain rates in deep waters. While $\mathrm{N}_{2}$ fixation rates per volume are most informative for budgetary calculations, rates normalized to PON concentration would provide an additional measure for comparing rates across studies. Further, variability of the natural $\delta^{15} \mathrm{~N}$ background of PON, changes in the $\delta^{15} \mathrm{~N}$ of PON that may occur over the incubation period or due to substrate additions, and $\delta^{15} \mathrm{~N}$ of the $\mathrm{N}_{2}$ pool, should be considered (Montoya et al., 1996; Gradoville et al., 2017). These sources of uncertainty are not routinely reported and detection limits are infrequently calculated. Taking into account these sources of error, Gradoville et al. (2017) estimated the minimum quantifiable $\mathrm{N}_{2}$ fixation rate in their study at $\sim 0.4 \mathrm{nmol} \mathrm{L}^{-1} \mathrm{~d}^{-1}$ which is higher than many reported rates of NCNF (Table 1).

To our knowledge, direct field measurements of $\mathrm{N}_{2}$ fixation per cell are currently lacking for marine NCDs; such measurements would be important in assessing their contribution to $\mathrm{N}_{2}$ fixation rates, along with other efforts to separate signals of $\mathrm{NCNF}$ and cyanobacterial $\mathrm{N}_{2}$ fixation (see also Bombar et al., 2016). High NCD nifH diversity renders identification and quantification of biogeochemically significant individual groups challenging. The combination of in situ hybridization approaches using halogenated probes together with single-cell mass spectrometry (nanoscale secondary ion mass spectrometry; nanoSIMS) has recently advanced quantification of single-cell $\mathrm{N}_{2}$ fixation rates in UCYN-A 
(Thompson et al., 2012; Krupke et al., 2013). Similar approaches could provide insights into the NCNF in marine environments. Stable isotope probing and isotope microarrays could lead to valuable future insights (Seyler et al., 2014; Arandia-Gorostidi et al., 2017).

In describing the communities, sequencing depth and primer specificity influence what portion of the NCD community is detected. In addition, the detection limit for diazotroph transcripts or genes and the detection limit for $\mathrm{N}_{2}$ fixation are not necessarily equal. The quantification limit of quantitative PCR is often on the order of $10^{2}$ nifH gene copies $\mathrm{L}^{-1}$ (and often unreported), which could potentially result in false negatives for cyanobacterial diazotrophs, and subsequently, lead to false positive NCNF rates. Using small water volumes when abundance of cyanobacterial diazotrophs is low would increase the chances of reporting false negatives for these organisms. On the other hand, metabolic rate measurements of microbial samples brought to the surface from aphotic depths may be underestimated (Tamburini et al., 2013), making both rate and transcription analyses of deep communities challenging.

\section{CONCLUSIONS}

Our compiled analysis of data illustrates that low $\mathrm{N}_{2}$ fixation rates were reported from marine environments where NCD abundance was high and cyanobacterial diazotrophs were low or undetected. NCD nifH sequences show a wider geographical and depth distribution in pelagic environments overall than their cyanobacterial counterparts. The emerging data suggest that the NCD communities are diverse but only a few groups have been identified that appear in several studies (Farnelid et al., 2011;

\section{REFERENCES}

Agusti, S., Gonzalez-Gordillo, J. I., Vaque, D., Estrada, M., Cerezo, M. I., Salazar, G., et al. (2015). Ubiquitous healthy diatoms in the deep sea confirm deep carbon injection by the biological pump. Nat. Commun. 6:7608. doi: $10.1038 /$ ncomms 8608

Arandia-Gorostidi, N., Weber, P. K., Alonso-Saez, L., Moran, X. A. G., and Mayali, X. (2017). Elevated temperature increases carbon and nitrogen fluxes between phytoplankton and heterotrophic bacteria through physical attachment. ISME J. 11, 641-650. doi: 10.1038/ismej. 2016.156

Benavides, M., Berthelot, H., Duhamel, S., Raimbault, P., and Bonnet, S. (2017). Dissolved organic matter uptake by Trichodesmium in the Southwest Pacific. Sci. Rep. 7:41315. doi: 10.1038/srep41315

Benavides, M., Bonnet, S., Hernandez, N., Martinez-Perez, A. M., Nieto-Cid, M., Alvarez-Salgado, X. A., et al. (2016). Basin-wide N2 fixation in the deep waters of the Mediterranean Sea. Glob. Biogeochem. Cycles 30, 952-961. doi: $10.1002 / 2015 \mathrm{gb} 005326$

Benavides, M., Moisander, P. H., Berthelot, H., Dittmar, T., Grosso, O., and Bonnet, S. (2015). Mesopelagic $\mathrm{N}_{2}$ fixation related to organic matter composition in the Solomon and Bismarck Seas (Southwest Pacific). PLoS ONE 10:e0143775. doi: 10.1371/journal.pone.0143775

Bentzon-Tilia, M., Severin, I., Hansen, L. H., and Riemann, L. (2015a). Genomics and ecophysiology of heterotrophic nitrogen-fixing bacteria isolated from estuarine surface water. MBio 6:e00929. doi: 10.1128/mBio.00929-15

Bentzon-Tilia, M., Traving, S. J., Mantikci, M., Knudsen-Leerbeck, H., Hansen, J. L., Stiig, M., et al. (2015b). Significant N2 fixation by heterotrophs,
Turk-Kubo et al., 2014). Studies on NCD nifH transcripts in aphotic layers are scarce or missing for many areas of the oceans.

We currently lack a fundamental understanding of the key players and environmental regulation of NCNF in the ocean. Ecophysiological data of the organisms contributing to these rates are still preliminary and incomplete. Moreover, the measured rates in most environments are generally "snapshots" determined during a cruise/sampling foray and have not been examined over seasonal and annual cycles. In addition, several methodological concerns complicate interpretation of $\mathrm{N}_{2}$ fixation rate data. Modeling the significance of NCNF in marine $\mathrm{N}_{2}$ fixation remains a challenge due to these various constraints. If these rates are confirmed, however, NCNF could contribute significantly to new $\mathrm{N}$ inputs to the ocean. How factors such as temperature, DIN, oxygen, trace elements, and hydrostatic pressure drive the metabolic capacities and adaptations of NCNF are currently only partially revealed. The actual activities and taxon specific roles of marine NCDs remain enigmatic at present, as do their contributions to regional and global $\mathrm{N}_{2}$ fixation.

\section{AUTHOR CONTRIBUTIONS}

PM and LR designed the study, wrote the initial drafts, and compiled the majority of Table 1. All authors wrote sections of the manuscript and contributed to Table 1.

\section{FUNDING}

PM was supported by NSF 1733610, AW was supported by NSF 1732206, and MB and LR were supported by grant 6108-00013 from the Danish Council for Independent Research to LR. photoheterotrophs and heterocystous cyanobacteria in two temperate estuaries ISME J. 9, 273-285. doi: 10.1038/ismej.2014.119

Berman-Frank, I., Chen, Y.-B., Gao, Y., Fennel, K., Follows, M. J., Milligan, A. J., et al. (2008). "Feedbacks between the nitrogen, carbon and oxygen cycles," in Nitrogen in the Marine Environment, 2nd Edn, eds D. G. Capone, D. A. Bronk, M. R. Mulholland, and E. J. Carpenter (Burlington, MA: Elsevier, Inc.), 1537-1563.

Berthelot, H., Benavides, M., Moisander, P. H., Grosso, O., and Bonnet, S. (2017). High nitrogen fixation rates in the particulate and dissolved pools in the Western Tropical Pacific (Solomon and Bismarck Seas). Geophys. Res. Lett. doi: 10.1002/2017GL073856. [Epub ahead of print].

Bird, C., and Wyman, M. (2013). Transcriptionally active heterotrophic diazotrophs are widespread in the upper water column of the Arabian Sea. FEMS Microb. Ecol. 84, 189-200. doi: 10.1111/1574-6941.12049

Bird, C., Martinez, J. M., O’Donnell, A. G., and Wyman, M. (2005). Spatial distribution and transcriptional activity of an uncultured clade of planktonic diazotrophic gamma-proteobacteria in the Arabian Sea. Appl. Environ. Microbiol. 71, 2079-2085. doi: 10.1128/AEM.71.4.2079-2085.2005

Blais, M., Tremblay, J.-E., Jungblut, A. D., Gagnon, J., Martin, J., Thaler, M., et al. (2012). Nitrogen fixation and identification of potential diazotrophs in the Canadian Arctic. Global Biogeochem. Cycles 26:GB3022. doi: 10.1029/2011GB004096

Bombar, D., Paerl, R. W., and Riemann, L. (2016). Marine non-cyanobacterial diazotrophs: moving beyond molecular detection. Trends Microbiol. 24, 916-927. doi: 10.1016/j.tim.2016.07.002

Bonnet, S., Caffin, M., Berthelot, H., and Moutin, T. (2017). Hot spot of N2 fixation in the western tropical South Pacific pleads for a spatial decoupling between 
N2 fixation and denitrification. Proc. Natl. Acad. Sci. U.S.A. 114, E2800-E2801. doi: $10.1073 /$ pnas.1619514114

Bonnet, S., Dekaezemacker, J., Turk-Kubo, K. A., Moutin, T., Hamersley, R. M., Grosso, O., et al. (2013). Aphotic $\mathrm{N}_{2}$ fixation in the Eastern Tropical South Pacific Ocean. PLoS ONE 8:e81265. doi: 10.1371/journal.pone.0081265

Bonnet, S., Rodier, M., Turk, K., Germineaud, C., Menkes, C., Ganachaud, A., et al. (2015). Contrasted geographical distribution of N2 fixation rates and nifH phylotypes in the Coral and Solomon Seas (South-Western Pacific) during austral winter conditions. Global Biogeochem. Cycles 29, 1874-1892. doi: 10.1002/2015GB005117

Brown, S. M., and Jenkins, B. D. (2014). Profiling gene expression to distinguish the likely active diazotrophs from a sea of genetic potential in marine sediments. Environ. Microbiol. 16, 3128-3142. doi: 10.1111/1462-2920.12403

Capone, D. G., Burns, J. A., Montoya, J. P., Subramaniam, A., Mahaffey, C., Gunderson, T., et al. (2005). Nitrogen fixation by Trichodesmium spp.: an important source of new nitrogen to the tropical and subtropical North Atlantic Ocean. Global Biogeochem. Cycles 19:GB2024. doi: 10.1029/2004GB 002331

Chien, Y.-T., and Zinder, S. H. (1996). Cloning, functional organization, transcript studies, and phylogenetic analysis of the complete nitrogenase structurel genes (nifHDK2) and associated genes in the archaeon Methanosarcina barkeri 227. J. Bacteriol. 178, 143-148. doi: 10.1128/jb.178.1.143-148.1996

Church, M. J., Ducklow, H. W., and Karl, D. A. (2004). Light dependence of H-3 leucine incorporation in the oligotrophic North Pacific ocean. Appl. Environ. Microbiol. 70, 4079-4087. doi: 10.1128/AEM.70.7.4079-4087.2004

Church, M. J., Jenkins, B. D., Karl, D. M., and Zehr, J. P. (2005a). Vertical distributions of nitrogen-fixing phylotypes at Stn ALOHA in the oligotrophic North Pacific Ocean. Aquat. Microb. Ecol. 38, 3-14. doi: 10.3354/ame038003

Church, M. J., Short, C. M., Jenkins, B. D., Karl, D. M., and Zehr, J. P. (2005b). Temporal patterns of nitrogenase gene (nifH) expression in the oligotrophic North Pacific Ocean. Appl. Environ. Microbiol. 71, 5362-5370. doi: 10.1128/AEM.71.9.5362-5370.2005

Dabundo, R., Lehmann, M. F., Treibergs, L., Tobias, C. R., Altabet, M. A., Moisander, P. H., et al. (2014). The contamination of commercial ${ }^{15} \mathrm{~N}_{2}$ gas stocks with ${ }^{15} \mathrm{~N}$-labeled nitrate and ammonium and consequences for nitrogen fixation measurements. PLOS ONE 9:e110335. doi: 10.1371/journal.pone.0110335

Dang, H., and Lovell, C. R. (2016). Microbial surface colonization and biofilm development in marine environments. Microbiol. Mol. Biol. Rev. 80, 91-138. doi: 10.1128/MMBR.00037-15

Dekaezemacker, J., Bonnet, S., Grosso, O., Moutin, T., Bressac, M., and Capone, D. G. (2013). Evidence of active dinitrogen fixation in surface waters of the eastern tropical South Pacific during El Nino and La Nina events and evaluation of its potential nutrient controls. Global Biogeochem. Cycles 27, 768-779. doi: $10.1002 / g b c .20063$

Dekas, A. E., Chadwick, G. L., Bowles, M. W., Joye, S. B., and Orphan, V. J. (2014). Spatial distribution of nitrogen fixation in methane seep sediment and the role of the ANME archaea. Environ. Microbiol. 16, 3012-3029. doi: 10.1111/1462-2920.12247

Dekas, A. E., Poretsky, R. S., and Orphan, V. J. (2009). Deep-sea archaea fix and share nitrogen in methane-consuming microbial consortia. Science 326, 422-426. doi: 10.1126/science. 1178223

Delmont, T. O., Quince, C., Shaiber, A., Esen, O. C., Lee, S. T. M., Lucker, S., et al. (2017). Nitrogen fixing populations of Planctomycetes and Proteobacteria are abundant in the surface ocean. BioRxiv. doi: 10.1101/129791

Deutsch, C., Sarmiento, J. L., Sigman, D. M., Gruber, N., and Dunne, J. P. (2007). Spatial coupling of nitrogen inputs and losses in the ocean. Nature 445, 163-167. doi: 10.1038/nature05392

Falcon, L. I., Carpenter, E. J., Cipriano, F., Bergman, B., and Capone, D. G. (2004). N-2 fixation by unicellular bacterioplankton from the Atlantic and Pacific oceans: phylogeny and in situ rates. Appl. Environ. Microbiol. 70, 765-770. doi: 10.1128/AEM.70.2.765-770.2004

Farnelid, H., Andersson, A. F., Bertilsson, S., Abu Al-Soud, W., Hansen, L. H., Sorensen, S., et al. (2011). Nitrogenase gene amplicons from global marine surface waters are dominated by genes of non-cyanobacteria. PLoS ONE 6:e19223. doi: 10.1371/journal.pone.0019223

Farnelid, H., Bentzon-Tilia, M., Andersson, A. F., Bertilsson, S., Jost, G., Labrenz, M., et al. (2013). Active nitrogen-fixing heterotrophic bacteria at and below the chemocline of the central Baltic Sea. ISME J. 7, 1413-1423. doi: 10.1038 /ismej.2013.26

Fay, P. (1992). Oxygen relations of nitrogen fixation in cyanobacteria Microbiol. Rev. 56, 340-373.

Fernandez, C., Farias, L., and Ulloa, O. (2011). Nitrogen fixation in denitrified marine waters. PLoS ONE 6:e20539. doi: 10.1371/journal.pone.0020539

Foster, R. A., Paytan, A., and Zehr, J. P. (2009). Seasonality of N-2 fixation and nifH gene diversity in the Gulf of Aqaba (Red Sea). Limnol. Oceanogr. 54, 219-233. doi: 10.4319/lo.2009.54.1.0219

Gradoville, M. R., Bombar, D., Crump, B., Letelier, R. M., Zehr, J. P., and White, A. E. (2017). Diversity and activity of nitrogen-fixing communities across ocean basins. Limnol. Oceanogr. doi: 10.1002/lno.10542. [Epub ahead of print].

Grosskopf, T., Mohr, W., Baustian, T., Schunck, H., Gill, D., Kuypers, M. M. M., et al. (2012). Doubling of marine dinitrogen-fixation rates based on direct measurements. Nature 488, 361-364. doi: 10.1038/nature11338

Halm, H., Lam, P., Ferdelman, T. G., Lavik, G., Dittmar, T., LaRoche, J., et al. (2012). Heterotrophic organisms dominate nitrogen fixation in the South Pacific Gyre. ISME J. 6, 1238-1249. doi: 10.1038/ismej.2011.182

Hamersley, M. R., Turk, K. A., Leinweber, A., Gruber, N., Zehr, J. P., Gunderson, T., et al. (2011). Nitrogen fixation within the water column associated with two hypoxic basins in the Southern California Bight. Aquat. Microb. Ecol. 63, 193-205. doi: 10.3354/ame01494

Hayat, R., Ali, S., Amara, U., Khalid, R., and Ahmed, I. (2010). Soil beneficial bacteria and their role in plant growth promotion: a review. Ann. Microbiol. 60, 579-598. doi: 10.1007/s13213-010-0117-1

Herridge, D. F., Peoples, M. B., and Boddey, R. M. (2008). Global inputs of biological nitrogen fixation in agricultural systems. Plant Soil 311, 1-18. doi: 10.1007/s11104-008-9668-3

Hewson, I., Moisander, P. H., Achilles, K. M., Carlson, C. A., Jenkins, B. D. Mondragon, E. A., et al. (2007). Characteristics of diazotrophs in surface to abyssopelagic waters of the Sargasso Sea. Aquat. Microb. Ecol. 46, 15-30. doi: 10.3354/ame046015

Hietanen, S., Lehtimäki, J. M., Tuominen, L., Sivonen, K., and Kuparinen, J. (2002). Nodularia spp. (Cyanobacteria) incorporate leucine but not thymidine: importance for bacterial-production measurements. Aquat. Microb. Ecol. 28, 99-104. doi: 10.3354/ame028099

Hood, R. R., Coles, V. J., and Capone, D. G. (2004). Modeling the distribution of Trichodesmium and nitrogen fixation in the Atlantic Ocean. J. Geophys. Res. 109:C06006. doi: 10.1029/2002JC001753

Jayakumar, A., Al-Rshaidat, M. M. D., Ward, B. B., and Mulholland, M. R. (2012). Diversity, distribution, and expression of diazotroph nifH genes in oxygen-deficient waters of the Arabian Sea. FEMS Microb. Ecol. 82, 597-606. doi: 10.1111/j.1574-6941.2012.01430.x

Karl, D., Michaels, A., Bergman, B., Capone, D., Carpenter, E., Letelier, R., et al. (2002). Dinitrogen fixation in the world's oceans. Biogeochemistry 57-58, 47-98. doi: 10.1023/A:1015798105851

Kirchman, D. L. (1990). Limitation of bacterial growth by dissolved organic matter in the subarctic Pacific. Mar. Ecol. Prog. Ser. 62, 47-54. doi: 10.3354/meps062047

Kirshtein, J. D., Paerl, H. W., and Zehr, J. P. (1991). Amplification, cloning, and sequencing of a nifH segment from aquatic microorganisms and natural communities. Appl. Environ. Microbiol. 57, 2645-2650.

Knapp, A. N. (2012). The sensitivity of marine N-2 fixation to dissolved inorganic nitrogen. Front. Microbiol. 3:374. doi: 10.3389/fmicb.2012.00374

Knapp, A. N., Casciotti, K. L., Berelson, W. M., Prokopenko, M. G., and Capone, D. G. (2016). Low rates of nitrogen fixation in eastern tropical South Pacific surface waters. Proc. Natl. Acad. Sci. U.S.A. 113, 4398-4403. doi: $10.1073 /$ pnas. 1515641113

Krupke, A., Musat, N., LaRoche, J., Mohr, W., Fuchs, B. M., Amann, R. I., et al. (2013). In situ identification and $\mathrm{N}_{2}$ and $\mathrm{C}$ fixation rates of uncultivated cyanobacteria populations. Syst. Appl. Microbiol. 36, 259-271. doi: 10.1016/j.syapm.2013.02.002

Langlois, R. J., LaRoche, J., and Raab, P. A. (2005). Diazotrophic diversity and distribution in the tropical and subtropical Atlantic ocean. Appl. Environ. Microbiol. 71, 7910-7919. doi: 10.1128/AEM.71.12.7910-7919.2005

Langlois, R. J., Mills, M. M., Ridame, C., Croot, P., and LaRoche, J. (2012). Diazotrophic bacteria respond to Saharan dust additions. Mar. Ecol. Prog. Ser. 470, 1-14. doi: 10.3354/meps10109 
Langlois, R., Grokopf, T., Mills, M., Takeda, S., and LaRoche, J. (2015). Widespread distribution and expression of Gamma A (UMB), an uncultured, diazotrophic, gamma-Proteobacterial nifH Phylotype. PLoS ONE10:e0128912. doi: 10.1371/journal.pone.0128912

Loescher, C. R., Grosskopf, T., Desai, F. D., Gill, D., Schunck, H., Croot, P. L., et al. (2014). Facets of diazotrophy in the oxygen minimum zone waters off Peru. ISME J. 8, 2180-2192. doi: 10.1038/ismej. 2014.71

Mahaffey, C., Michaels, A. F., and Capone, D. G. (2005). The conundrum of marine N-2 fixation. Am. J. Sci. 305, 546-595. doi: 10.2475/ajs.305.6-8.546

Man-Aharonovich, D., Kress, N., Bar Zeev, E., Berman-Frank, I., and Beja, O. (2007). Molecular ecology of nifH genes and transcripts in the eastern Mediterranean Sea. Environ. Microbiol. 9, 2354-2363. doi: 10.1111/j.1462-2920.2007.01353.x

Mehta, M. P., and Baross, J. A. (2006). Nitrogen fixation at 92 degrees C by a hydrothermal vent archaeon. Science 314, 1783-1786. doi: 10.1126/science. 1134772

Messer, L. F., Mahaffey, C., Robinson, C. M., Jeffries, T. C., Baker, K. G., Isaksson, J. B., et al. (2016). High levels of heterogeneity in diazotroph diversity and activity within a putative hotspot for marine nitrogen fixation. ISME J. 10, 1499-1513. doi: 10.1038/ismej.2015.205

Mohr, W., Grosskopf, T., Wallace, D. W. R., and LaRoche, J. (2010). Methodological underestimation of oceanic nitrogen fixation rates. PLOS ONE 5:e12583. doi: 10.1371/journal.pone.0012583

Moisander, P. H., Beinart, R. A., Voss, M., and Zehr, J. P. (2008). Diversity and abundance of diazotrophic microorganisms in the South China Sea during intermonsoon. ISME J. 2, 954-967. doi: 10.1038/ismej.2008.51

Moisander, P. H., Serros, T., Paerl, R. W., Beinart, R. A., and Zehr, J. P. (2014). Gammaproteobacterial diazotrophs and nifH gene expression in surface waters of the South Pacific Ocean. ISME J. 8, 1962-1973. doi: 10.1038/ismej.2014.49

Moisander, P. H., Shiue, L., Steward, G. F., Jenkins, B. D., Bebout, B. M., and Zehr, J. P. (2006). Application of a nifH oligonucleotide microarray for profiling diversity of $\mathrm{N}$-2-fixing microorganisms in marine microbial mats. Environ. Microbiol. 8, 1721-1735. doi: 10.1111/j.1462-2920.2006.01108.x

Moisander, P. H., Zhang, R., Boyle, E. A., Hewson, I., Montoya, J. P., and Zehr, J. P. (2012). Analogous nutrient limitations in unicellular diazotrophs and Prochlorococcus in the South Pacific Ocean. ISME J. 6, 733-744. doi: 10.1038/ismej.2011.152

Montoya, J. P., Voss, M., Kähler, P., and Capone, D. G. (1996). A simple, highprecision, high-sensitivity tracer assay for $\mathrm{N}_{2}$ fixation. Appl. Environ. Microbiol. 62, 986-993.

Mortenson, L. E., and Thorneley, R. N. F. (1979). Structure and function of nitrogenase. Ann. Rev. Biochem. 48, 387-418. doi: 10.1146/annurev.bi.48.070179.002131

Mulholland, M. R., Bernhardt, P. W., Heil, C. A., Bronk, D. A., and O'Neil, J. M. (2006). Nitrogen fixation and release of fixed nitrogen by Trichodesmium spp. in the Gulf of Mexico. Limnol. Oceanogr. 51, 1762-1776. doi: 10.4319/lo.2006.51.4.1762

Postgate, J. (1998). Nitrogen Fixation, 3rd Edn. New York, NY: Cambridge University Press.

Rahav, E., Bar-Zeev, E., Ohayon, S., Elifantz, H., Belkin, N., Herut, B., et al. (2013a). Dinitrogen fixation in aphotic oxygenated marine environments. Front. Microbiol. 4:227. doi: 10.3389/fmicb.2013.00227

Rahav, E., Giannetto, M. J., and Bar-Zeev, E. (2016). Contribution of mono and polysaccharides to heterotrophic N2 fixation at the eastern Mediterranean coastline. Sci. Rep. 6:27858. doi: 10.1038/srep27858

Rahav, E., Herut, B., Stambler, N., Bar-Zeev, E., Mulholland, M. R., and BermanFrank, I. (2013b). Uncoupling between dinitrogen fixation and primary productivity in the eastern Mediterranean Sea. J. Geophys. Res. 118, 195-202. doi: 10.1002 /jgrg. 20023

Riemann, L., Farnelid, H., and Steward, G. F. (2010). Nitrogenase genes in noncyanobacterial plankton: prevalence, diversity, and regulation in marine waters. Aquat. Microb. Ecol. 61, 235-247. doi: 10.3354/ame01431

Severin, I., Bentzon-Tilia, M., Moisander, P. H., and Riemann, L. (2015). Nitrogenase expression in estuarine bacterioplankton influenced by organic carbon and availability of oxygen. FEMS Microb. Lett. 326:fnv105. doi: 10.1093/femsle/fnv105

Seyler, L. M., McGuinness, L. M., and Kerkhof, L. J. (2014). Crenarchaeal heterotrophy in salt marsh sediments. ISME J. 8, 1534-1543. doi: 10.1038/ismej.2014.15

Shiozaki, T., Ijichi, M., Kodama, T., Takeda, S., and Furuya, K. (2014). Heterotrophic bacteria as major nitrogen fixers in the euphotic zone of the Indian Ocean. Global Biogeochem. Cycles 28, 1096-1110. doi: $10.1002 / 2014 \mathrm{~GB} 004886$

Short, S. M., and Zehr, J. P. (2007). Nitrogenase gene expression in the Chesapeake Bay Estuary. Environ. Microbiol. 9, 1591-1596. doi: 10.1111/j.1462-2920.2007.01258.x

Sohm, J. A., Hilton, J. A., Noble, A. E., Zehr, J. P., Saito, M. A., and Webb, E. A. (2011). Nitrogen fixation in the South Atlantic Gyre and the Benguela Upwelling System. Geophys. Res. Lett. 38:L16608. doi: 10.1029/2011GL048315

Tamburini, C., Boutrif, M., Garel, M., Colwell, R. R., and Deming, J. W. (2013). Prokaryotic responses to hydrostatic pressure in the ocean - a review. Environ. Microbiol. 15, 1262-1274. doi: 10.1111/1462-2920.12084

Thiele, S., Fuchs, B. M., Amann, R., and Iversen, M. H. (2015). Colonization in the photic zone and subsequent changes during sinking determine bacterial community composition in marine snow. Appl. Environ. Microbiol. 81, 1463-1471. doi: 10.1128/AEM.02570-14

Thompson, A. W., Foster, R. A., Krupke, A., Carter, B. J., Musat, N., Vaulot, D., et al. (2012). Unicellular cyanobacterium symbiotic with a single-celled eukaryotic alga. Science 337, 1546-1550. doi: 10.1126/science.1222700

Turk-Kubo, K. A., Karamchandani, M., Capone, D. G., and Zehr, J. P. (2014). The paradox of marine heterotrophic nitrogen fixation: abundances of heterotrophic diazotrophs do not account for nitrogen fixation rates in the Eastern Tropical South Pacific. Environ. Microbiol. 16, 3095-3114. doi: 10.1111/1462-2920.12346

Wilson, S. T., Boettjer, D., Church, M. J., and Karl, D. M. (2012). Comparative assessment of nitrogen fixation methodologies, conducted in the oligotrophic North Pacific Ocean. Appl. Environ. Microbiol. 78, 6516-6523. doi: 10.1128/AEM.01146-12

Yogev, T., Rahav, E., Bar-Zeev, E., Man-Aharonovich, D., Stambler, N., Kress, N., et al. (2011). Is nitrogen fixation significant in the Levantine Basin, East Mediterranean Sea? Environ. Microbiol. 13, 854-871. doi: $10.1111 / j .1462-2920.2010 .02402 . x$

Zehr, J. P. (2011). Nitrogen fixation by marine cyanobacteria. Trends Microbiol. 19, 162-173. doi: 10.1016/j.tim.2010.12.004

Zehr, J. P., Jenkins, B. D., Short, S. M., and Steward, G. F. (2003). Nitrogenase gene diversity and microbial community structure: a cross-system comparison. Environ. Microbiol. 5, 539-554. doi: 10.1046/j.1462-2920.2003.00451.x

Zehr, J. P., Mellon, M. T., and Zani, S. (1998). New nitrogen-fixing microorganisms detected in oligotrophic oceans by amplification of nitrogenase (nifH) genes. Appl. Environ. Microbiol. 64, 3444-3450.

Zehr, J. P., Mellon, M., Braun, S., Litaker, W., Steppe, T., and Paerl, H. W. (1995). Diversity of heterotrophic nitrogen fixation genes in a marine cyanobacterial mat. Appl. Environ. Microbiol. 61, 2527-2532.

Zehr, J. P., Harris, D., Dominic, B., and Salerno, J. (1997). Structural analysis of the Trichodesmium nitrogenase iron protein: implications for aerobic nitrogen fixation activity. FEMS Microb. Lett. 153, 303-309. doi: 10.1111/j.1574-6968.1997.tb12589.x

Conflict of Interest Statement: The authors declare that the research was conducted in the absence of any commercial or financial relationships that could be construed as a potential conflict of interest.

Copyright (c) 2017 Moisander, Benavides, Bonnet, Berman-Frank, White and Riemann. This is an open-access article distributed under the terms of the Creative Commons Attribution License (CC BY). The use, distribution or reproduction in other forums is permitted, provided the original author(s) or licensor are credited and that the original publication in this journal is cited, in accordance with accepted academic practice. No use, distribution or reproduction is permitted which does not comply with these terms. 